\title{
Hate Content on Kenyan Social Media Space: How the Social Media is Propagating the Spread of Hate Messages in Kenya
}

\author{
Mwongela Francis*, Wenje Peres, Gathii Njenga, John Kirimi M'Raiji \\ Masinde Muliro University of Science and Technology
}

*Corresponding Author: Mwongela Francis, Masinde Muliro University of Science and Technology

\begin{abstract}
This article analyses the use of Social Media in propagation of hate messages in Kenya. It establishes the presence of hate content on social media, the extent of exposure to hate messages among social media users, explores the nature of hate messages on social media and determines the diffusion (flow and spread) of hate messages online. Social media can play a key role in advocacy of human rights, preventing atrocities like genocide, ethnic cleansing, mutinies, rebellions, and revolts, and mobilization to a course. It can also be used to span ethnic hatred, religious intolerance, radicalization, racial divisions and spreading of hate messages. By informing, educating and perhaps sometimes by deceiving, the media in any society is the epicenter of the events palpable; such is the power of the media. However, this power of the mainstream media is experiencing competition as well as boost from the social media coupled by fastgrowing technology. Inasmuch as the mainstream media is self-regulatory in various aspects, in the matter hate speech, the law is specifically in the ambit of the State. To the contrary, social media is an open field devoid of a grip of control. This coupled by vague legal framework on hate speech, has provided a fertile ground for spread of hate content. Conversely, hate speech is becoming one of the greatest tools to spur violence, mass atrocities, ethnic hatred, radicalization, and religious intolerance among other discords. This aspect needs to be taken into consideration and addressed firmly. Few studies have been carried out to address the aspect of new media technologies and hate speech.
\end{abstract}

Keywords: Hate content, communication, new media, technology and social media

\section{INTRODUCTION}

Over Time, assertions have been rife in many spheres on what constitutes hate messages. Developing countries especially in Africa have been hard hit with violence and uprisings in the recent past to what could be blames to such. However, what can be drawn and asserted to lead to advocacy of national, ethnicity, racial or and religious hatred that constitutes incitement to discrimination, hostility or violence, prohibited by Article 20 of the International Covenant on Civil and Political Rights (ICCPR) often precedes mass atrocities like genocide, civil wars, mass and forceful displacements of populations and war (ICCPR, 1966).

Some communication scholars argue that there should be more restrictions levied on some speeches and freedoms of media at particular social settings in order and specific dimensions to prevent such atrocities and enhance peace prosperity. To the contrary, other commentators argue that not all hate speech reaches the level of prohibited hate speech and a clear threshold must be developed (Ringera, 2010). It is worth noting that, for instance in Kenya, there is a National Cohesion And Integration Commission (NCIC), tasked with a mandate to ensure Kenyans live amicably without such issues as hatred, discrimination among others and also send early warnings to the government of the day in case such magnitudes of hate speech and hatred crop up (NCIC, 2008).

Historically, information is a key factor in beginning of conflicts around the World. The media plays an important role of a watchdog in the society; exposing to the public what is essential but hidden, however, it can also be used to mobilize for violence and or hatred. There is the mainstream media also known as traditional media and social media. Social media can act as a tool for widening the democratic space; however, can also lead to destabilization of peace and spring of violence. Messages and information are instant; newsrooms, as places for editing news are being overtaken; raw information is sent by anybody to everybody unedited. Journalism has been stolen! Information, whether likely to generate hate or bring peace goes out uncensored! (Jeffrey, 2002) 
The growth of Social media enthusiasm in the world has been tremendous with the rapid growth in technology. Gizmos that are internet enabled and availability of cheap internet are key factors. Therefore then, social media is coming up as a fast growing tool to reach out to people especially the youth. The Social Networking Sites (SNS) are providing cost-effective platforms to communicate with large population with zero time difference. Noting that media is a powerful tool of communication, media literacy is an issue that cannot be ignored. It is therefore pertinent to evaluate the potential impacts that social media play especially Facebook in propagating hate speech and hate messages (Marinkovic\& Rowe, 2013).

Incitement to violence or ethnic hatred, including by ordinary citizens or politicians, community leaders or journalists, has actually resulted in massive violence and mass killings in many countries across the continent. Rwanda presents the most extreme examples of how the relationship between a government, the media and politics can go horribly wrong. But throughout the continent, there are sporadic instances of alleged incitement resulting in massive violence, such as in Kenya, Ivory Coast, Uganda, Burundi, Nigeria, etc. Unfortunately, the jurisprudence on incitement cases remains very limited, with the exception of South Africa. Many charges of incitement have never been actually investigated or pursued to the end in a court of law.

The emergence of social media, has dared to liberalize communication; this is due to the involvement of the mass or individual audience in the creation and dissemination of information perhaps from an individual to mass or otherwise through incidental messages. This has thus altered the role and design of traditional media in information dissemination and created a room to what is referred to as citizen journalism. Social media has provided a means of constant and immediate communication, which link individuals and persons globally and locally; anybody can publish anything from anywhere. Kaplan, and M. Haenlein 2010, argue that social media has caused a shift in the communication environment which was previously dominated by the mass media, in fact breaking news are no longer such.

\section{DISCUSSION}

\subsection{The Concept of Hate Message}

Hate message generally has been defined as a speech that attacks a person(s) or a group on the basis of color, origin, race, religious affiliation, gender, or sexual orientation. It is also a communication disparaging a racial, sexual, or ethnic group or a member of such a faction. Outside the law, communication that vilifies a person or a group based on discrimination against that person or group (NCIC, 2010).From a legal perspective, hate speech/ hate communication is any speech, gesture or conduct, writing, or display which is forbidden for it may incite violence or prejudicial action against or by a protected individual or group, or because it disparages or intimidates a protected individual or group (Mulei, et al 2003).

\subsection{Legal Jurisdictions on Hate Speech}

There are various treaties, pacts, agreements and conventions, which have globally all touched and laid emphasis on the doctrine of hate speech. The International Covenant on Civil and Political Rights (ICCPR) states that any advocacy of national, racial or religious hatred that constitutes incitement to discrimination, hostility or violence shall be prohibited by law (ICCPR, 1996).

All governments have a duty to prohibit hate speech by adoption of a domestic legislation; this is one of the limitations to the freedom of expression and right to speech by citizens of any democratic nation. However, this should be viewed as respect of the rights and reputation of others; and for the protection of national security and or public order, or of public health and or public morality (McGonagle, 2012).

\subsection{The Concept of Language and New Media Technologies}

Language is one of the greatest inventions that man ever had in civilization and during prehistory. It is this discovery that over the years has made communication an innate aspect of humanity. Channels of communication however, have been in constant evolution just as language has been. Media, has, emerged out of growth of humanity and development since antiquity (Meiller, 2009). It has become one of the major channels of communication henceforth; However, mainstream has been a 
domineering as a communication, which include broadcast media (Television and Radio) as well as print media (newspapers, reviews, magazines among others).

The elites in Africa own and control the mainstream media to their advantage either economically, socially or politically. To this end, Mainstream media has been accused of manufacturing consent; manipulating and relaying information that represent the interest of their owners and the ruling class especially in $3^{\text {rd }}$ world nations (Meiller, 2009).

The ruling class enjoy media protection and political economy (Jeffrey, 2002). The ownership of the media houses is split between political actors which have given the Kenyan media a long continued support in terms of buying space and airtime for advertising.

It is worth noting that the new media which has also referred to as social media has entered the stage and completely revolutionizing communication in terms of time, and content. It has complemented main stream media in relaying information to the masses. The mostly used social media platforms include; Facebook, Twitter, Whatsapp, Google chat, Skype, Yahoo chat Instagram, MySpace, LinkedIn among others (Tommo, 2012). In March 2010 there were a little over two million Facebook accounts according to the Communication Council of Kenya CCK; in 2014, this number has doubled to slightly 4 million accounts in Kenya. This accounts for about 9 percent of the entire population. A great majority of those on social media are the youth (Kaplan, and Haenlein, 2010)

The popularity of facebook has been attributed to the easy access from cell phones; there is a Short Message Service SMS to Facebook for instance, that sends a text to the users on every time something happens on Facebook (Tommo, 2012). There is also an application called Facebook zero, a text only free version of Facebook launched in 2010 in collaboration with mobile providers, which has brought Facebook to a larger number of people who prior to that did not have access to it.

Social media is also accessible by via computers that are internet enabled or connected. Computer literacy levels in Kenya have also grown tremendously in the $21^{\text {st }}$ century. The 2008 Consumer Insight Limited study reported that 74 percent of the population in Nairobi had used a computer at least once in their lifetime (CIL 2008). Back in 2009, Synovate, on other hand had estimated that in 30 percent of the Kenyan urban population used the internet weekly (ITU 2010).

Twitter is a social networking site more or less like Facebook; the only difference is that Tweets, (twitter messages), have a maximum of 140 characters long. Facebook has a limit of 5,000 friends for every member account, there are no such limits on followers on one's Twitter handle. However, on facebook, one can have a fun-page with limitless likes or a group which can also have many likes (Tommo, 2012). Like the mainstream media, social media is also powerful in shaping opinions and setting public agenda. As such, on political undertones, social media can ignite violent conflicts in a nation.

Respectively, they view the social media's rapid growth in popularity as a catalyst that will inevitably lead to more transparency in governance and democracy, and conversely the elitist protagonists, only see the danger that uncontrolled communication might pose to a country, nation or a society. Notably, the Arab spring and uprisings in the Middle East and North Africa in early 2011 has prompted calls on the need of rigorous study into the potential role social media can play in conflict escalation, prevention and peace building and reconciliation. In these countries, protesters across the region relied on varying degrees on social media to organize protests against the governments of the day. They also leveraged on international news organizations and perhaps non-governmental bodies to solicit for international support and sympathy (Kaplan, and Haenlein, 2010).

Recognizing the power of social media, in that their contents are uncensored, the governments made asserting controls over social media platforms a top priority as a reactionary measure to coil violence. For instance, Former Egyptian president Hosni Mubarak banned access to Twitter, Facebook, YouTube and Google in the first few days of the protest, he then shut down internet on $28^{\text {th }}$ January 2011. Former Libyan ousted leader president Gaddafi's security officers blocked all internet traffic in and out of the country, in response, the international community redirected funds towards programs that aimed at strengthening media in the North African region (Kaplan, and Haenlein, 2010). These leaders, viewed social media wave as the trailer to hate messages spiking revolts to their unprecedented revolutionary fate and imminent ousters. 
However, to the contrary, on the legal aspect, Article 20 of the ICCPR remains unclear and problematic on issues that may qualify as hate messages. A further elaboration of the ICCPR standards needs to be developed to define hate messages. Courts, all of over the world; both at the domestic and international levels, Africa included, have grappled with these issues with an array of results. At the domestic levels, countries have not been able to develop clear definition in their disparate bodies of laws. Similarly, domestic courts have not given any consistent interpretation of what may be constitutive components of speech as such to be defined as "promotion of national, racial or religious hatred that constitutes incitement to prejudice, antagonism or violence."However, some law enforcement agencies in various countries may be seen to be pro-government of the day; they tend, at times to brand any political speech they do not agree with as geared at incitement to hatred (ICCPR, 1996).

\subsection{The Concept of Social Media}

Social media refers to the means of interaction among people in which they create share and or exchange information ideas in virtual communities or networks using technology based applications. Heanlein (2010) defines social media as a group of internet based applications that build on the ideological and technological foundations of the web and that allow the creation and exchange of user-generated content. The content might include text, video, images, podcasts and other multimedia communications. The most prominent examples of social media include, Facebook, Twitter, LinkedIn, Reddit, Google +, Google talk, Yahoo chat, Skype, Whatsapp (Kaplan, M. and Michael Haenlein 2010).

Facebook is a popular free social networking website that allows registered users to create profiles, upload photos and video, send messages and keep in touch with friends' family and colleagues. Twitter is a free micro blogging service that allows registered members to broadcast posts called tweets. Twitter members can broadcast tweets and follow other user's tweets by using multiple platforms and devices (Tommo, 2012).

\section{THE CONCEPT OF HATE MESSAGES}

\subsection{The Grounds for Hatred}

In many African countries' jurisdictions, the term "hatred" generally covers racial, ethnic, national and religious hatred and in the same manner (McGonagle, 2012). It some countries it often also covers hatred on the grounds of sex, political convictions, language, social status or physical or mental disability.

In the case of Kenya, the Constitution in Article 27 guarantees equality and freedom from discrimination. In Article 27 (4) it outlaws direct and indirect discrimination against any person on any ground, including race, sex, pregnancy, marital status, health status, ethnic or social origin, colour, age, disability, religion, conscience, belief, culture, dress, language or birth. The Constitution through Article 33 (1) also guarantees freedom of expression (Constitution ofKeny $a, 2010$ )

It is worth noting that the National Cohesion and Integration Act in section 13(1) states that "a person who uses ... which is threatening, abusive or insulting or involves the use of threatening, abusive or insulting words or behaviour commits an offence if such a person intends thereby to stir up ethnic hatred, or having regard to all the circumstances, ethnic hatred is likely to be stirred up." (NCIC, 2011)

\subsection{Hate Content on Social Media Space}

Hate speech discourses on social media in critical events are likely to lead to the demystification of sociopolitical actors, as well as to an overall uncertainty among citizens which might finally result in their political disengagement and social fabric determent. Moreover, in a public space where messages of hatred and intolerance are allowable, people might feel unease and intimidated to express their points of view. In other words, hate speech on a popular social media platform such as Twitter, and facebook can possibly obstruct the constructive process of deliberation, and threaten democracy and peace. Also, the fact that it is very hard -if not impossible- to control and regulate hate speech content on social media, intensifies the need to identify and make sense of the hate speech phenomenon in order to find the right solution for its diminution without challenging the right to free expression (Sevasti, 2014). This study seeks establish the presence of this hate content on social media in its varying degrees. 
Whereas hate speech, most of the times takes cue, when there have to be uttered or spoken word (s), such words may also be written in a book, a newspaper, a pamphlet, a brochure, or expressed in a public performance. The spoken word must be capable of being understood by the audience as stirring hatred directed at a particular section of the population. Publication may entail the actual printing of the material containing hate speech as well as physical handing out of the material to the public or sections of the population (NCIC, 2008). Social media platforms being channels of communications expose people in varying degrees to hate speech in varying degrees.

The Social Networking sites (SNS) are providing cost-effective platforms to communicate with large populations with zero time difference. Noting that media is a powerful tool of communication, media literacy is an issue that cannot be ignored (Parekh, 2012). It is therefore pertinent to evaluate the potential impacts that social media especially facebook in propagating hate speech in Kenya.

Mostly, growing democracies and economies face various challenges; economic, social and political. Hate messages would be of different contexts in such a circumstance of a developing nation; economic, social or political wrangles are obvious (Matas, 2000). Political rivalry, social injustices and economic struggles may push populations to blaming others for their woes. This often may push for hatred. Most of the times the only option to vent is the readily available social media which goes uncensored.

Further, hate messages that are communicated and spread via different social media are in different forms. Some may be in form of pictures (cartoons), in coded languages, and others in outright and straight forward language. Bloggers and micro bloggers may have incidental posts of hate messages posted on their timelines (Jaishnkar, 2008). Others may decide to either share the message, like the messages, or comment on them. Either way, the hate messages have been spread.

\subsection{The Threshold and Tests for Hate Messages}

There is need to measure threshold and intensity of hate messages in a robust and codified threshold before speech is deemed "hate speech". This is essential for the promotion of coherent legislation and sound international, regional and national jurisprudence in this area (McGonagle 2012). According to Dworkin (1997), the following variables could be used: Severity, Intent, Content, Extent, in particular the public nature of the speech, Imminence, Likelihood or probability of action, and Context.

Intent can be also determined from the scale and repetition of the communication (e.g. if the inciter repeated the communication over time or on several occasions, it might be more likely that there was an intent to incite the action). However, if the court can identify a legitimate objective (such as "historical research, the dissemination of news and information, and the public accountability of government authorities") for the speech, other than to incite to discrimination, hostility or violence, then the speech should fall short of the threshold (McGonagle, 2012).

The content of the speech constitutes one of the key foci of the court's deliberations and is a critical element of incitement (Dworkin, 1997). Content analysis may include a focus on the form, style, nature of the arguments deployed in the speech at issue or in the balance struck between arguments deployed, etc.

\subsection{The Likelihood or Probability of Harm Occurring}

Incitement, by definition, is an inchoate crime. The action advocated through incitement speech does not have to be committed for that speech to amount to a crime. Nevertheless some degree of risk of resulting harm must be identified. It means the courts will have to determine that there was a reasonable probability that the speech would succeed in inciting actual action, recognizing that such causation should be rather direct (Dworkin, 1997).

Context is of great importance when assessing whether particular statements are likely to incite to hatred and it may bear directly on both intent and/or causation. Unfortunately, as noted by Mendel,

It is extremely difficult to drawn any general conclusions from the case law about what sorts of contexts are more likely to promote the proscribed result, although common sense may supply some useful conclusions. Indeed, it sometimes seems as though international courts rely on a sample of contextual factors to support their decisions rather than applying a form of objective reasoning to deduce their decisions from the context. Perhaps the impossibly broad sets of factors that constitute context make this inevitable. 


\subsection{Historical Contexts of the Incitement Related Regulations}

Many countries in the region share a similar history of colonialism and white supremacy (and the apartheid regime in South Africa) during which large scale violations of human rights occurred. These regimes were characterized by the policy of "divide" which was aimed at ensuring white hegemony and dividing population along racial and ethnic lines. The legacy of these violations still persists in the region and is often manifested in deep divides in the societies, especially in the Southern African region (McGonagle, 2012).

These definitions of class and ethnicity played roles in ethnic conflicts, including the 1994 genocide in Rwanda. Moreover, during the colonial and apartheid time, the calls for national liberation or against white oppression were prosecuted under incitement laws. For example, in South Africa, the laws prohibiting racial hostility were, according to available information, only applied against antiapartheid opponents of the government (Human Rights Watch, HRC, 2008). A large number of laws still on the book in many Africancountries, including those related to incitement to hatred, or those regulating the media, dates back to colonial regimes and thus to political regimes that had enshrined racism as a core value (e.g. Zimbabwe). Even if the laws in question are not used, their continuing existence is highly problematic at many levels (Kakai, 2010).

\subsection{A Case of Kenya's Hate Speech Social Media}

Himelboim et al. (2013) argues that groups, friend connections, fan pages and 'followers' on SNS result in people forming ideologically homogenous clusters which can in turn facilitate a discourse of 'us' vs. 'them' especially in matters politics (Sevasti, 2014)

Quite often on social media, ordinary discussion around politics generates strong opinions especially on polarizing issues or when there is a clear divide in the political environment. Some of these conversations degenerate into personalized attacks and the expression of bigoted views which in turn provoke strong reactions and the cycle continues.

Ethnicity has been the Key driver of politics in the Kenyan society. Different observers have argued that political discourse, voting behavior, political party affiliations, public opinion are all informed by ones ethnic identity (Maweu, 2012, Wanyama 2010, Kagwanja, 2005). The evolution of politics, the ushering of multiparty democracy and the evolution of new media technology have not necessary altered the established ethnic voting patterns; in any case, they have been entrenched as some have observed. Maweu (2013) argues that modern ethnicized politics are now executed through new media, particularly social media.

Maweu further notes that there was a captive calm during the 2013 general elections with mainstream media calling for calm and engaging in what has now been labeled as 'peace propaganda'. The European Union Elections Observation Mission noted the active participation by the media in calling for calm. Major news outlets exercised great restraint and self-censorship to avoid falling into the mistakes of 2007/2008 when the Kenyan media was accused of having incited and promoted ethnic tensions. She however argues that 'as the mainstream media censored itself to ensure peace and calm in the country, the country was 'burning' through ethnic hate messages transmitted through social media".

Kenya, like most African nations experiences increased tension close to election period. The divisions and passions are mostly driven by the political choices of the ethic 'kingpins' in their quest for political power. In 2007 and 2013, the major political players commanded a huge following among their ethnic bases and coalitions were built based on ethnic calculations.

The character of national debate is normally reflected in the online spaces. The period immediately before and after the 2013 general elections, social media became the battle ground for divergent political views and in some cases, civility disappeared and debate degenerated to alarming levels inflaming passions. The character of online political debate is such that certain 'opinion leaders' on social media acting on their own or at the behest of political leaders post controversial issues provoking instant response from those with supporting or opposing views and some cases debate spirals out of control as bigotry takes over.

Maweu (2013) observes that in the 2013 electioneering period, the Kenyan social media space experienced highly inciting speech similar to what was witnessed in 2007, including openly advocating for violence, murder and eviction of certain communities especially those associated with the major political players. 
Benesch, (2014) argues that in the Kenyan election of 2013, the accusation of hate speech was used as a political weapon to surpass debate during an election when it was more needed than ever.

\subsection{The Use of Social Media (Facebook and Twitter) to Impact Sociopolitical Change in Recent Times}

Several scholars have documented how social media was used as the main medium of communication that brought change to political leadership in Northern African states and the Middle East. The studies have shown how social media was instrumental in coordinating the protests during the uprising. They have also documented how civilians in authoritarian regimes relied on social media to champion their political rights. Middle East countries and Northern African have been further discussed in this study because they exemplified the most recent ways in which social media has been used to coordinate uprisings that later became revolutions. These regions have exposed the potential of social media in coordination and how social finds its place during conflicts (Kaplan, and Haenlein, 2010).

\subsection{Social Media Revolution Criticism}

Some critics argue that social media tools are ineffective; Christensen for instance claims that platform of social media are built around weak ties and are only effective at increasing participation and on the other hand they lessen the motivation the participation requires. He says that people need close personal connection in order to get them take action, especially if it is announced through social media and the nature of action is risky and difficult (Meiller, 2009). Then there are also logistical issues that arise, there were only $20 \%$ of the entire population that used internet in the Egyptian revolution (most concentration being in Cairo). Despite the limited access to the social media like Facebook and Twitter, there was a tremendous amount of pressure generated from the onset Cairo (Joudon, 2011). There was the unofficial role played by the trade unions in the protests that was downplayed, away from the trade unionists there were drivers, factory workers and the Suez Canal laborers, nurses, doctors who finally brought down President Hosni Mubarak.

Political theorists also claim that techno-utopian overstate the affordability of the new technologies while understating other underlying factors of their acquisition and use. Economic or gender issues for instance could affect their accessibility as well as other prevalent conditions in the country (Meiller, 2009).

In Libya and Yemen for instance the severe totalitarian regimes stymied reform efforts, and at the core of the revolution there was a force that was more willing to criticize the authority and tolerates diversity than perhaps the mainstream public opinion. The case in Lebanon was different; the activists began to unite with the goal of outdoing the sectarian system. They managed to reach about 15,000 people through a Facebook group entitled "In favor of ousting the Lebanese sectarian system toward a secular system", the group comprised of youths from different sects, regions and cultural backgrounds. It is thus the sectarian and divided nature of the Lebanese youth partisanship that rendered it difficult to use social media to mobilize the young people through a common goal. This is clear illustration that the prevailing conditions can affect the outcome of the use of the social media when rallying behind a common goal (Joudon, 2011).

There is powerful evidence that social media can improve understanding and help establish ties between traditionally opposing groups. Facebook's own project a partnership with the Peace Pot Initiative at Stanford University called "Peace on Facebook". The initiative counted new friendship formation on the site between people who come from groups with a history of difficult relations. The count is done in revealing connections established across geographic division; E.g. friends between antagonizing political blocs, different ethnic groups or religious groups among others.

On March $11^{\text {th }}$ 2012, there were 123,844 online connections which were made between conflicting Muslims and Jews. It would be a gross oversimplification to suggest that these counts necessarily represent concrete progress towards greater real world harmony. However they do reflect the way that social media can help to maintain relationships online that may prove difficult in person due to social censure, political or logistical constraints (Joudon, 2011).

\subsection{In The Case of Kenya: Social Media and Hate Speech}

In late 2007 and early 2008 most Kenyans didn't have access to the internet as they do presently (Saila, 2012), not even through cell phones as today. Those who were online experienced a wave of heightened activity. Many experienced the down side of uncontrolled communication, but others were 
able to even save lives though their blog posts and social media accounts. There was a strong intersexuality within these communications and SMS messages have therefore been included in as the new media. (Iraki, 2010).

Mäkinen and Kuira argue that 'the social media functioned as an alternative medium for citizen communication or participatory journalism' but it was also used 'as channels for biased information, tribal prejudices, and hate speech. Goldstein and Rotich continue in the same vein by stating that digitally networked technologies 'were a catalyst to both predatory behavior such as ethnic-based mob violence and to civic behavior such as citizen journalism and human rights campaigns' during the post-election crisis. (Goldstein and Rotich, 2009).

According to Wa-Mungai (2010) there was a strong intertextuality between sources of information and the means used to disseminate the information. Mass e-mails were shortened to fit SMS and Twitter accounts and mixed with rumors. (Wa-Mungai, 2010) 'Like SMS, cyberspace-based discussions were also fed on rumors and misinformation from the press.' (wa-Mungai, 2010). The majority of those who participated in these discussions was pro-RailaOdinga and expressed despair for the 'failure of democracy.' (Wa-Mungai, 2010)

Due to the rampant spread of SMS messages the government decided, despite a weak legal standing on the issue, to send a warning: 'The government of Kenya advises that the sending of hate messages inciting violence is an offence that could result in prosecution.' (wa-Mungai, 2010). This warning did not ring on empty ears as many of the respondents stated clearly that they were wary in fear of government action.

\subsection{Example of Hate Content on Social Media in Kenya}

Politicians are also starting to take note of the social and most now have Facebook or Twitter accounts, as well as blogs that they use for campaigns. There are signs that government is taking online activism seriously and taking action in scrutinizing content online. The audiences are aware of this and some of them fear that the state machinery have expressed the possibility of a repetition of the postelection violence and incitement towards ethnic divisions (Sid, 2010). However there has been caution for those who are posting content online with political sensitivity to exercise self-censorship. For instance, the Gatundu South MP hon. Moses Kuria is alleged to be notorious of hate content on social media particularly a Facebook account purported to be his.

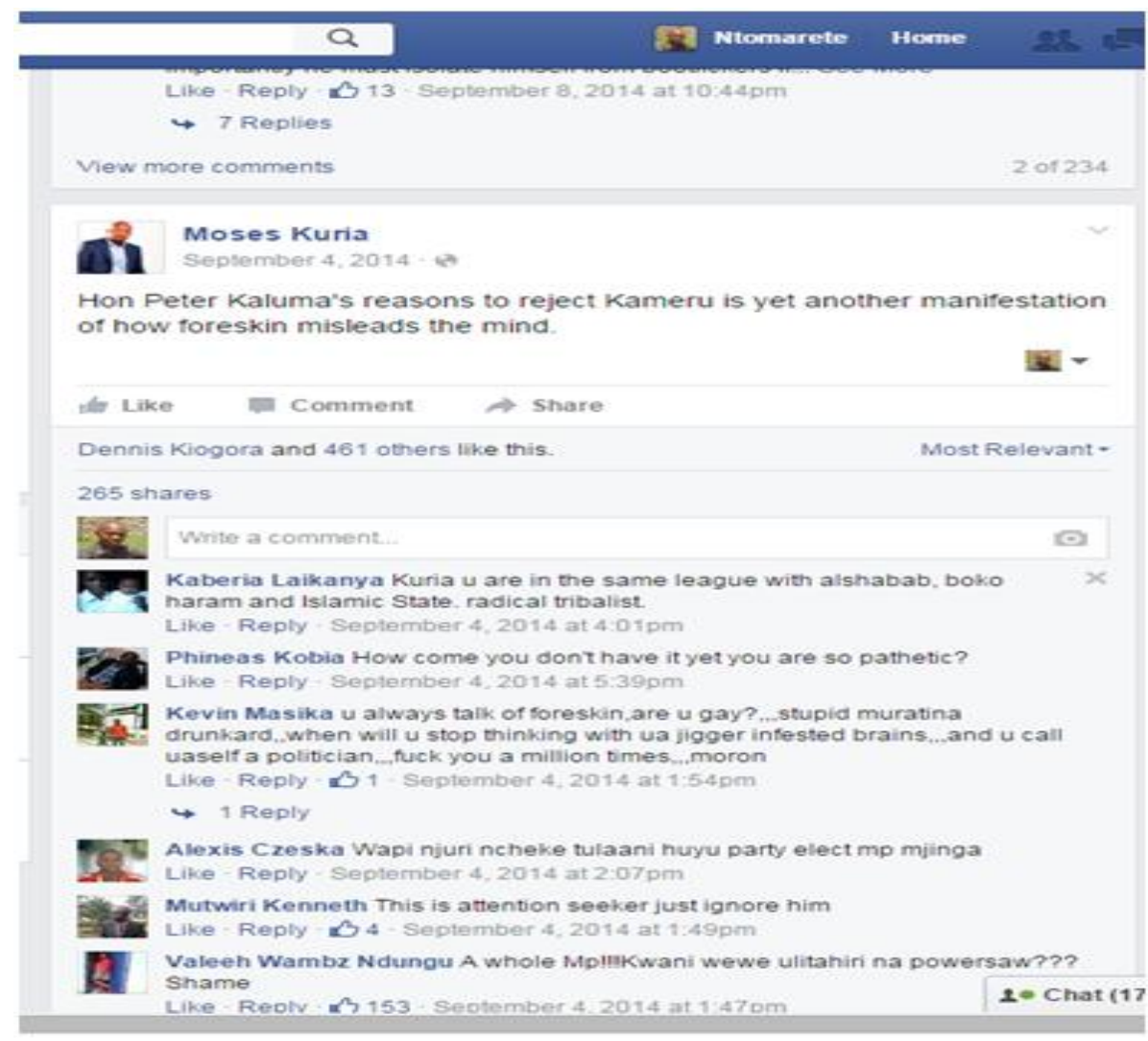

Snapshot of alleged hate content: source facebook.com/MosesKuria 
Kuria's statement referring to Hon. Kaluma's decision to reject the said, is a twin hate on politics and ethnicity. However, reactions from one respondent notably KaberiaLaikanya "kuria $u$ are in the same league with Alshabaab, Boko Haram and Islamic state. Radical tribalist". This comment brings an aspect of religious hate to the effect by linking Islam as a religion to terrorism. To infer how hate speech is spread, the post has been 'shared' by 265 persons and liked by 461 persons on social media from the time it was posted to when the study used it; $4^{\text {th }}$ September 2014 and $23^{\text {rd }}$ August 2015 . This shows that to the minimum over 1000 persons read this post.

Another notable example of hate content on social is by a political analyst MutahiNgunyi on his social networking site twitter:

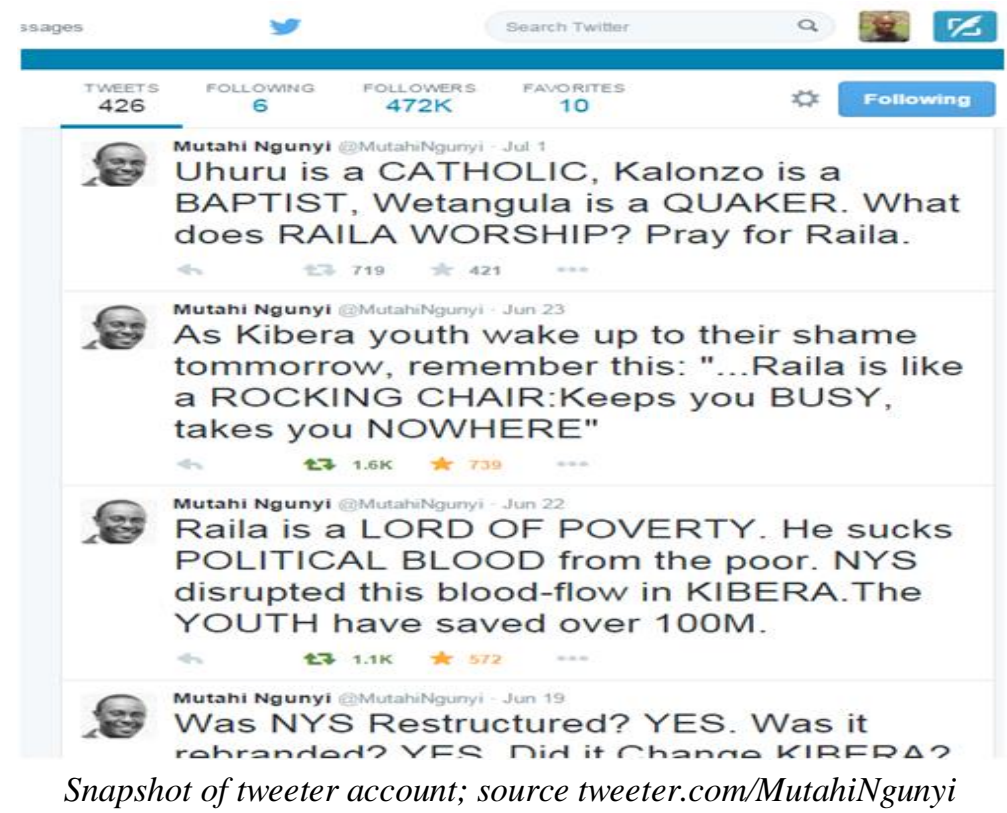

Mutahi's comments came after turbulence in political balance in the alleged corruption in the Ministry of Devolution and Planning in 2015 department of National Youth Service, where funds were alleged to have been lost through corrupt deals. Raila Odinga being the leader of the opposition was vocal in calling on the resignation of the then Cabinet Secretary in the docket. The posts above are a combination of religious, political and ethnic hatred.

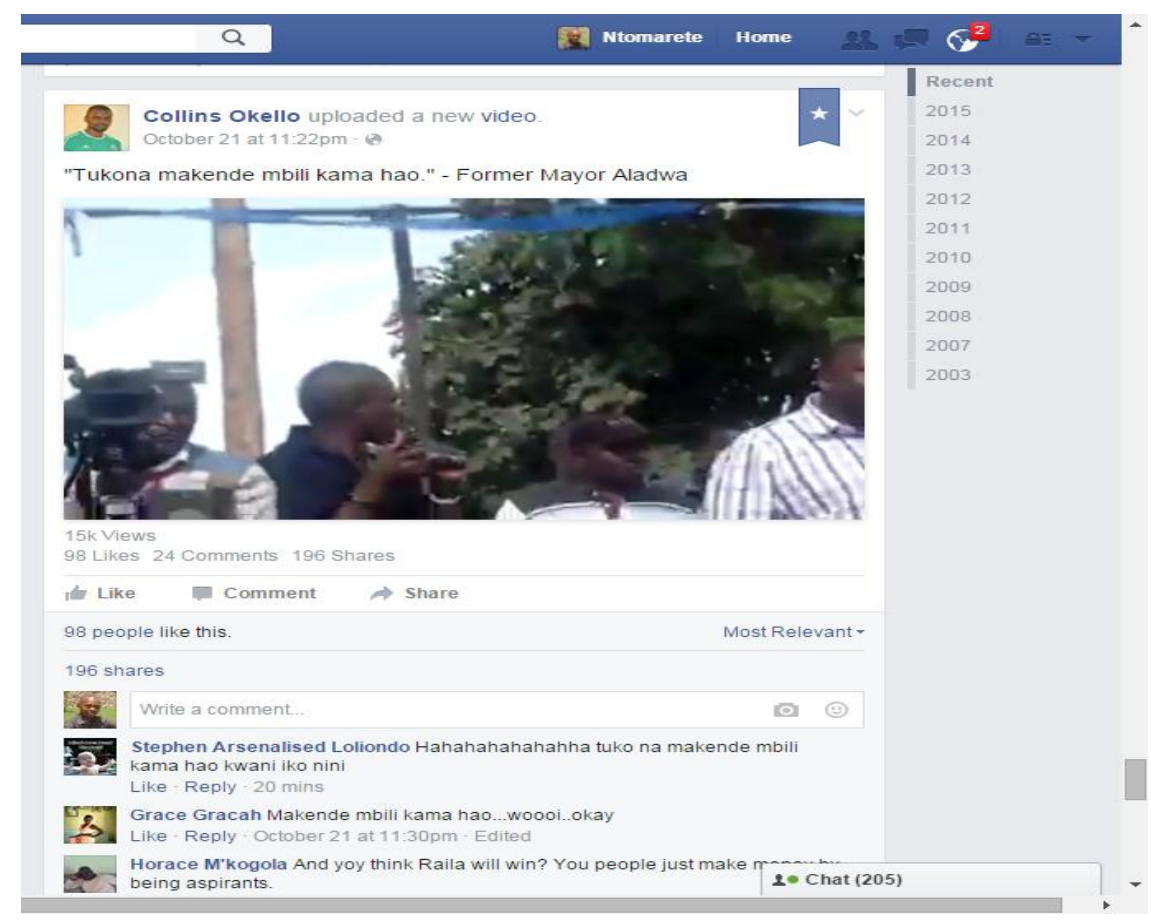

Snapshot of Hate Content on Aladwa; Source Facebook.Com/Collinsokelo 
The former Nairobi mayor George Aladwa is alleged to have spoken words dubbed hateful in Kenya's Kibera slum in an opposition rally during the Kenya's Mashujaa day celebrations on the $20^{\text {th }}$ October 2015. Kenyans took on twitter to quote him and even upload videos on social media. A notable example is one Collins Okello as above, who quoted a portion of alleged hateful content and even uploaded the clip, "hatasisitukonamakendembilikamawao...". 'wao' in this context may be taken to refer to Kikuyus and Kalenjins if taken in the context of Kenya's political ethnic base and environment of the speaker.

\section{CONCLUSION}

The review of some of the existing materials on new media technologies and hate speech has shed more light on the aspect under research. Key aspects have come out clearly. The Growth in technology is a double edged sword to communication. Inasmuch as there are benefits attached to it, the challenges are equally enormous. A case to site is the growth of and emergence of various social networking sites. Social media, as a communication and information platform is growing tremendously each day. This growth has presented new challenges and opportunities every other time. One of the greatest challenges is a threat to peace and stability. Perhaps, this is due to the silence of legal framework on the aspect of spreading hate messages insofar as the technology is concerned. Loopholes exist in taming online hate speech propagation. For instance there is no existing law that restricts a media house or an individual from sharing hate content in Kenya. Hate speech is becoming a volatile social and philosophical problem. For instance, unlike in the instances of most globally recognized offences, there is no universally agreed upon definition of what hate speech is. As a result what one will find is that different culture and countries or regions have banned expressions that can be included in this general concept, in different intensities.

However, hate speech, generally refers to words of incitement and hatred against individual(s) based on a certain group characteristics they share. It includes, but not limited to speech that advocates or encourages violent acts against a specific group, and creates a climate of hate or prejudice, which may in turn promote the commission of hate crimes. The identification of expressions that could be qualified as "hate speech" is difficult. Sometimes even civilized individuals spread hatred unawares. For example if one asserts that 'no Meru man can take care of a Meru lady like a Luo man', that out rightly to the speaker may have had fun intended, but some Meru men may not take it lightly. Note that this kind of speech does not necessarily manifest itself through the direct expression of hatred or of emotions. It can also be concealed in statements which at first glance may seem to be rational or normal. In this regard, we can have intentional and unintentional hate speech. In this study, the study, therefore then focuses, to investigate the role played by social media in propagation of hate speech.

\section{REFERENCES}

[1] Article 19 Commentary (2010) "Kenya: Article 19 Recommends Amendments to "Hate Speech" Laws and Proposed Constitution" Press Release.

[2] Asmat. Uddin \& Harris Tarim (2013), "Rethinking the Red Line"; the interaction of free speech, religious freedom and social change, USA

[3] Attorney GeneralKenya (2008) The National Cohesion and Integration Act. The National Council For Law Reporting NCLR

[4] Attorney GeneralKenya (2010)The Constitution of Kenya. Nairobi, Kenya

[5] Bhikhu Parekh 'is there a case for banning hate speech? In M, Herz and P. Molnar (eds), The content and context of hate speech, Cambridge CUP 2012 pg 37)

[6] Caroline J. Tommo (2012), Journalism and social media, Kenya

[7] Castells, Manuel et al. (2004) 'The Mobile Communication Society: A cross-cultural analysis of available evidence on the social uses of wireless communication technology,' Annenberg Research Network on International Communication.

[8] ChristoforouSevasti (2014) Social media and political communication: Hate speech in the age of twitter Unpublished Thesis. Erasmus University of Rotterdam

[9] CiriloMarinkovic\& Brianna Rowe (2013) “Kenya Domestic Media Monitor Report."Migs Media Monitoring Reporters 
Hate Content on Kenyan Social Media Space: How the Social Media is Propagating the Spread of Hate Messages in Kenya

[10] Cowan, Ruth Schwarz (1983). More Work for Mother: The Ironies of Household Technology from the Open Hearth to the Microwave. New York: Basic Books.

[11] Croteau, D., Hoynes, W. (2003). Media Society: Industries, Images and Audiences ((third edition) ed.). Thousand Oaks: Pine Forge Press..

[12] Dworkin, R. (1997). Taking rights seriously, Massachusetts: Harvard university press

[13] EvelyneAsaala, TJRC Rapporteur (2009) "Exploring Transitional Justice as a Vehicle for Social and Political Transformation In Kenya.” African Human Rights Law Journal

[14] G.A. Cohen, 1978, Karl Marx's Theory of History: A Defence, Oxford and Princeton.

[15] Griffin, E. (1997). A first look at communication theory (3rd ed.). New York: McGraw-Hill

[16] Human Rights Watch (HRC) (2008) Ballots to Bullets: Organised Political Violence and Kenya's Crisis of Governance

[17] International Crisis Group (2008) Kenya in Crisis, Africa report No. 137, published on 28 February 2008.

[18] ITU (International Telecommunication Union) (2010) ICT Statistics Newslog - National survey shows Kenyan Internet market heading towards "critical mass"

[19] Jaishankar K. 2008, Cyber Hate: Antisocial Networking in the internet, International Journal of Cyber Criminology

[20] John T Nockleby, Hate Speech inEncyclopedia of the American constitution

[21] Kaplan, M. and Michael Haenlein (2010) 'Users of the world, unite! The challenges and opportunities of Social Media,' Business Horizons 53. pp 59-68.

[22] Kenan Malik 2012 - The content and context of hate speech, Cambridge, Cambridge University Press

[23] Klaehn, Jeffrey (2002) 'A critical Review and Assessment of Herman and Chomsky's Propaganda Model,' European Journal of Communication, 17, pp.147-174.

[24] Kwamchetsi M. (2010) 'The Dynamics and Politics of Media in Kenya: The Role and Impact of Mainstream Media in the 2007 General Elections,' in KarutiKanyinga and Duncan

[25] Mäkinen, Maarit and Wary WanguKuira (2008) 'Social Media and Post-election Crisis in Kenya,' Press/Politics, 13(3).

[26] Matas D. Bloody words: Hate and free speech Winnipeg, Bain and Cox, 2000, pg 55

[27] Maweu J. (2013), the ethnic hate speech was networked: what political discussions on social media reveal about the 2013 general elections in Kenya, University of Nairobi, Kenya.

[28] Meiller P., (2009) Applying Technology to crisis mapping and early warning in humanitarian settings. UNDP New York.

[29] Mulei, C. et al (2003). Media law and practice in Kenya, Nairobi: phoenix publishers

[30] NCIC (2010) “Guidelines For Monitoring Hate Speech In The Electronic Media In Kenya."

[31] NCIC (2011)“The National Cohesion and Integration Training Manual."

[32] NCIC "Guiding Questions on the Development of the Policy for National Cohesion and Integration."

[33] NCIC Annual Report 2009 - 2010.

[34] Ringera, Karambu (2010) 'The Politics of Media Culture and Media Culture Politics,' in Wa-Mungai, Mbugua and George Gona (eds.), (Re) Membering Kenya: Identity, Culture and Freedom, Nairobi: Twaweza Communications.

[35] Robert Post Hate speech in Hare and Weinstein, Extreme speech and democracy, op, pp 123-4

[36] Robin Wilson, Rapporteur (2012) “Indignity, Indifference, Indignation: Tackling Hate Speech Online. "Report of the Conference "Tackling Hate Speech: Living Together Online"

[37] Saila, Lindrous (2011) Facebook and Peace in Nairobi. University of Amsterdam press Amsterdam

[38] The Standard on Sunday (24.4.2011) Hassan Omar Hassan 'Kenyans should fight impunity with zeal equal to Arab World's.'

[39] The Sunday Nation (17.4.2011) MukhisaMituyi 'Arab revolution is coming: Check your Facebook.'

[40] Truth Justice and Reconciliation Commission of Kenya (TJRC, 2011)

[41] Volova, N., Silvestri, M., \& Lopez, S., (199) Hate Speech and the MediaThe Council of Europe

[42] Wa-Mungai, Mbugua (2010) 'Soft Power,' Popular Culture and the 2007 Elections,' in KarutiKanyinga and Duncan Okello (eds.), Tensions and Revisals in Democratic Transitions: The Kenya 2007 General Elections, Nairobi: Society for International Development. 
Hate Content on Kenyan Social Media Space: How the Social Media is Propagating the Spread of Hate Messages in Kenya

[43] Wanyonyi, Pius Kakai (2010) 'Historicizing Negative Ethnicity in Kenya,' in Wa-Mungai, Mbugua and George Gona (eds.), (Re) Membering Kenya: Identity, Culture and Freedom, Nairobi: Twaweza Communications.

Citation: Mwongela Francis, et.al. "Hate Content on Kenyan Social Media Space: How the Social Media is Propagating the Spread of Hate Messages in Kenya". International Journal of Media, Journalism and Mass Communications (IJMJMC), vol 5, no. 3, 2019, pp. 13-24 doi: http://dx.doi.org/10.20431/2455-0043.0503002

Copyright: (C) 2019 Authors. This is an open-access article distributed under the terms of the Creative Commons Attribution License, which permits unrestricted use, distribution, and reproduction in any medium, provided the original author and source are credited. 